\title{
PENINGKATAN KUALITAS DAN KETAHANAN NASI MENGGUNAKAN SARI BUAH NANAS (Ananas comosus L. Merr)
}

\author{
Harni Sepryani, Rosa Devitria \\ Akademi Analis Kesehatan Pekanbaru \\ Jln. Riau Ujung No. 73 Pekanbaru \\ E-mail: harni.sepriyani@univrab.ac.id
}

\begin{abstract}
Abstrak
Nasi merupakan salah satu makanan pokok bagi penduduk Indonesia. Nasi berfungsi sebagai sumber energi bagi manusia. Penelitian ini dilakukan untuk meningkatkan kualitas dan ketahanan nasi dengan menambahkan sari buah nanas (Ananas comosus L. Merr). Sari buah nanas digunakan sebagai pengawet alami pada nasi yang dimasak dan disimpan di dalam magic com. Buah nanas mengandung senyawa asam sitrat yang mampu menghambat pertumbuhan bakteri, kapang, dan ragi. Asam sitrat mampu merusak membran bakteri dan memisahkannya dari sel. Buah nanas juga mengandung enzim bromelin yang dapat berfungsi untuk memecah protein membran sel bakteri. Nasi yang sudah ditambahkan sari buah nanas akan disimpan di dalam magic com hingga 72 jam. Sari buah nanas ditambahkan pada nasi dengan konsentrasi $1 \%$. $\mathrm{pH}$, kandungan karbohidrat dan protein diukur pada 0 dan 72 jam penyimpanan nasi. $\mathrm{pH}$, kandungan karbohidrat, dan protein pada nasi meningkat setelah 72 waktu penyimpanan.
\end{abstract}

Kata kunci: Nasi, Ph, Karbohidrat, Protein

\section{PENDAHULUAN}

Beras merupakan makanan pokok bagi sebagian besar penduduk Indonesia. Beras mudah disajikan, enak, dan mempunyai nilai energi yang cukup tinggi. Konsumsi beras berpengaruh terhadap aktivitas tubuh dan kesehatan (Ariyadi dan Anggraini, 2010). Beras dapat diolah menjadi berbagai jenis makanan, salah satunya adalah nasi. Beras menyerap air selama proses pematangan dengan melepaskan zat tepung yang terkandung di beras, sehingga nasinya akan menjadi lengket satu dengan yang lainnya setelah matang. Dahulu beras dimasak secara tradisional menggunakan dandang yang dipanaskan di atas tungku dengan api dari kayu bakar. Nasi yang dimasak secara tradisional membutuhkan waktu yang lama, kebersihan nasi tidak terjamin, dan nasi harus segera dihabiskan (Andreas, 2009).

Saat ini masyarakat telah menggunakan magic com untuk memasak nasi. Magic com dapat membuat nasi tetap hangat dan lunak, tetapi penyimpanan yang terlalu lama dapat menurunkan kualitas nasi. Nasi akan menjadi berwarna kekuningan, berbau, dan perubahan rasa (Haq. dkk, 2010).

Perubahan pada nasi yang disimpan di dalam magic com disebabkan oleh suplai listrik yang tidak stabil, sehingga temperatur di dalam magic com tidak mencapai kondisi optimum, akibatnya bakteri akan muncul dan menyebabkan nasi menajdi basi. Magic com juga dapat mengalami penyumbatan pada lubang untuk pengeluaran uap air jika tidak dibersihkan. Penyumbatan ini 
menyebakan terganggunya sirkulasi udara di dalam magic com. Uap yang seharusnya keluar, tetap tertahan dan mengembun di bagian tutup magic com. Uap air yang kaya nutrisi ini sangat disukai oleh bakteri, sehingga mikroba akan tumbuh dan nasi menjadi basi.

Buah nanas (Ananas comosus L. Merr) mengandung senyawa asam sitrat seperti jeruk nipis. Asam sitrat mampu menghambat pertumbuhan bakteri, kapang, dan ragi. Asam sitrat mampu merusak membran bakteri dan memisahkannya dari sel. Buah nanas juga mengandung enzim bromelin yang dapat berfungsi untuk memecah protein membran sel bakteri (Rohmana., dkk, 2015). Penggunaan buah nanas sebagai pengawet alami telah dilakukan oleh Rohmana., dkk (2015) pada ikan bandeng (Chanos chanos forsk), setelah diawetkan sampel nasi mengalami kenaikan kadar protein sebesar $0,858 \%$. Pada penelitian ini akan dilakukan pengawetan nasi dengan menggunakan sari buah nanas. Nasi yang telah diawetkan akan dilakukan identifikasi warna, bau, tekstur dan $\mathrm{pH}$ dari nasi selama 0 sampai 72 jam. Kadar protein dan karbohidrat pada nasi yang telah diawetkan dengan sari buah nanas juga akan dianalisis sebagai nutrisi penting dalam nasi.

\section{METODOLOGI PENELITIAN Desain Penelitian}

Penelitian ini akan dilaksanakan di laboratorium Universitas Abdurrab dan laboratorium kimia dasar Universitas Riau. Penelitian akan dibagi menjadi beberapa tahap. Tahap pertama yaitu preparasi sari buah nanas dan memasak nasi yang telah ditambahkan sari buah nanas. Tahap kedua Pengukuran pH dilakukan analisis $\mathrm{pH}$ menggunakan $\mathrm{pH}$ meter, karbohidrat menggunakan metode Luff schroll dan protein menggunakan metode Lowry pada 0 dan 72 jam.

\section{Instrumen Pelaksanaan}

Alat-alat yang digunakan dalam penelitian ini adalah timbangan analitik, sentrifugasi, vortex, stopwatch, spektrofotometer Uv-Vis, buret, statis, magic com, blender, $\mathrm{pH}$ meter, pisau dan beberapa peralatan gelas yang disesuaikan dengan prosedur kerja. Bahan-bahan yang digunakan adalah beras, nanas, $\mathrm{Na}_{2} \mathrm{CO}_{3}$, $\mathrm{Na}_{2} \mathrm{SO}_{4}$, NaK-Tartarat, $\mathrm{CuSO}_{4}$, reagen phenol, $\mathrm{NaOH}$, larutan $\mathrm{HCl}, \mathrm{CH}_{3} \mathrm{COOH}$, pereaksi Luff schroll, $\mathrm{H}_{2} \mathrm{SO}_{4}, \mathrm{KI}, \mathrm{Na}_{2} \mathrm{~S}_{2} \mathrm{O}_{3}$ $0,1 \mathrm{~N}$, indikator amilum, buffer asetat $\mathrm{pH}$ 5,5 , bovine serum albumin, dan akuades.

\section{Prosedur Penelitian}

\section{Preparasi nanas}

Nanas sebanyak satu buah dikupas lalu dicuci dan dipotong-potong. Nanas yang sudah dipotong kemudian dihaluskan menggunakan blender dan disaring untuk mendapatkan sari dari buah nanas. Sari buah nanas dibuat pada konsentrasi $1 \%$.

\section{Pembuatan nasi}

Beras dicuci dengan air kemudian dimasak menggunakan magic com. Sari buah nanas ditambahkan ke dalam beras yang akan dimasak sesuai dengan variasi konsentrasi yang telah ditentukan. Beras dimasak \pm 30 menit. Setelah nasi matang, nasi disimpan di dalam magic com dan dipanaskan secara terus menerus selama 0 -72 jam.

Nasi yang telah dimasak menggunakan sari buah nanas dengan 
konsentrasi tertentu diukur nilai $\mathrm{pH}$ pada 0 dan 72 jam. Pengukuran $\mathrm{pH}$ nasi dilakukan menggunakan $\mathrm{pH}$ meter.

\section{Analisis kandungan karbohidrat}

Analisis karbohidrat pada nasi dilakukan menggunakan metode Luff Schroll dilakukan pada nasi 0 dan 72 jam. Nasi yang telah matang diblender untuk dijadikan sampel. Sampel yang telah diblender ditimbang sebanyak 5 gram dan dimasukkan ke dalam erlenmeyer. Selanjutnya sampel ditambahkan $120 \mathrm{~mL}$ $\mathrm{HCl} 3 \%$ dan direfluks selama 3 jam. Larutan didinginkan dan dinetralkan dengan $\mathrm{NaOH} 30 \%$, kemudian ditambahkan $\mathrm{CH}_{3} \mathrm{COOH} 3 \%$ agar suasana larutan sedikit asam. Larutan dipindahkan ke dalam labu ukur $500 \mathrm{~mL}$, tambahkan 25 $\mathrm{mL}$ larutan Luff schroll dan akuades. Campuran tersebut dipanaskan hingga mendidih selama 3 menit. Proses pendidihan dilanjutkan selama 10 menit. Selanjutnya campuran didinginkan dengan segera dalam bak berisi es. Setelah dingin campuran ditambahkan $25 \mathrm{~mL} \mathrm{H}_{2} \mathrm{SO}_{4} 25 \%$ dan 15 mL KI 20\% secara perlahan-lahan. Kemudian campuran dititrasi dengan larutan baku $\mathrm{Na}_{2} \mathrm{~S}_{2} \mathrm{O}_{3}, 0,1 \mathrm{~N}$ menggunakan indikator amilum $0,5 \%$.

\section{Analisis kandungan protein}

Kandungan protein pada nasi dianalisis dengan metode Lowry pada 0 dan 72 jam. Sampel dimasukkan ke dalam tabung reaksi, lalu ditambahkan $9,8 \mathrm{~mL}$ $\mathrm{Na}_{2} \mathrm{CO}_{3} 2 \%, 0,1 \mathrm{~mL}$ NaK-Tartarat 2,7\%, dan $0,1 \quad \mathrm{~mL}^{\mathrm{CuSO}} 4 \quad 1 \%$. Campuran dihomogenkan dan didiamkan selama 10 menit pada suhu ruang. Setelah itu, campuran ditambahkan $1 \mathrm{~mL}$ reagen fenol, dicampurkan, kemudian didiamkan kembali selama 30 menit pada suhu ruang. Absorbansi larutan berwarna yang tebentuk diukur menggunakan Spektrofotometer Uv-Vis pada panjang gelombang $700 \mathrm{~nm}$. Perlakuan yang sama dilakukan terhadap blanko yaitu buffer asetat $0,05 \mathrm{M}$ pH 5,5 dan larutan standar protein yang dibuat pada berbagai konsentrasi protein. Hasil absorbansi yang diperoleh, digunakan untuk menentukan konsentrasi protein sampel.

\section{Analisis Data}

Penentuan pH, kandungan
karbohidrat dan protein dilakukan
pengulangansebanyak 2 kali untuk setiap
sampel. Data yang diperoleh dari
penelitian tersebut disajikan dalam bentuk
tabel. Hasil penelitian yang diperoleh
dibahas secara deskriptif dan dibandingkan
dengan literatur.

\section{HASIL DAN PEMBAHASAN}

Hasil

Nilai pH, karbohidrat, dan protein pada nasi

Nilai $\mathrm{pH}$, karbohidrat, dan protein pada nasi diukur saat 0 dan 72 jam waktu penyimpanan. Pengukuran $\mathrm{pH}$ nasi dilakukan dengan menggunakan $\mathrm{pH}$ meter. Kadar karbohidrat pada nasi dilakukan dengan menggunakan metode Luff Schroll. Kadar protein pada nasi dilakukan dengan menggunakan metode Lowry. Hasil pengukuran dapat dilihat pada Tabel 2 . 
Tabel 2. Nilai pH, Karbohidrat, Dan Protein Nasi.

\begin{tabular}{lccccc}
\hline \multirow{2}{*}{ Parameter } & \multirow{2}{*}{ Pengukuran } & \multicolumn{4}{c}{ Waktu Penyimpanan (jam) } \\
\cline { 3 - 6 } & & $\mathbf{0}$ & Rerata & $\mathbf{7 2}$ & Rerata \\
\hline $\mathrm{pH}$ & I & 6,24 & \multirow{2}{*}{6,24} & 6,49 & \multirow{2}{*}{6,49} \\
& II & 6,24 & & 6,49 & \\
\hline Karbohidrat (\%) & I & 0,317 & \multirow{2}{*}{0,317} & 0,456 & \multirow{2}{*}{0,456} \\
& II & 0,317 & & 0,456 & \\
\hline Protein (ppm) & I & 0,143 & \multirow{2}{*}{0,143} & 3,329 & \multirow{2}{*}{3,809} \\
& II & 0,143 & & 3,048 & \\
\hline
\end{tabular}

\section{Pembahasan}

Efektivitas sari buah nanas sebagai pengawet alami pada nasi diamati melalui pengukuran $\mathrm{pH}$, kadar karbohhidrat, dan protein. Lama penyimpanan nasi di dalam magic com selama 0 hingga 72 jam. Sari buah nanas yang ditambahkan ke dalam nasi dengan konsentrasi $1 \% \mathrm{~b} / \mathrm{b}$. Konsentrasi ini dilakukan berdasarkan penelitian Haq., dkk, 2010. Sari buah nanas mengandung asam sitrat dan enzim bromelein yang tidak disukai bakteri.

Penentuan kadar dilakukan menggunakan metode Luff Schroll. Pengujian karbohidrat dengan metode ini $\mathrm{pH}$ larutan harus diperhatikan dengan baik, karena $\mathrm{pH}$ yang terlalu rendah (terlalu asam) akan menyebabkan hasil titrasi menjadi lebih tinggi dari sebenarnya, karena terjadi reaksi oksidasi ion iodida menjadi iodium. Apabila $\mathrm{pH}$ terlalu tinggi (terlalu basa), maka hasil titrasi akan menjadi lebih rendah dari pada sebenarnya, karena pada $\mathrm{pH}$ tinggi akan terjadi resiko kesalahan, yaitu terjadi reaksi iodium yang terbentuk dengan air (hidrolisis) (Sherwood, 2012).

Nasi yang disimpan selama 0 jam memiliki rata-rata kadar karbohidrat $0,317 \%$. Nasi yang disimpan selama 72 jam memiliki rata-rata $0,456 \%$. Menurut hasil penelitian Haq., dkk (2010) penggunaan sari buah jeruk nipis terhadap ketahanan nasi, kadar karbohidrat terlihat meningkat seiring dengan tingginya konsentrasi sari buah jeruk nipis yang ditambahkan. Hal ini menunjukkan bahwa semakin banyak sari buah jeruk nipis yang ditambahkan, semakin banyak jumlah bakteri yang mati sehingga jumlah karbohidrat pada nasi mendekati utuh karena seperti yang kita ketahui bahwa bakteri membutuhkan glukosa untuk memperoleh energi. Kenaikan kadar karbohidrat pada jam 72 juga terjadi karena adanya pengurangan kadar air sehingga konsentrasi karbohidrat dalam nasi menjadi lebih pekat.

Protein merupakan salah satu sumber energi bagi tubuh. Protein sebagai zat pembangun yang merupakan bahan pembentukan jaringan baru yang selalu terjadi di dalam tubuh. Salah satu sumber protein yang dapat diperoleh yaitu dari nasi. Nasi dapat disimpan dalam waktu tertentu dengan penambahan sari buah nanas. Berdasarkan hasil penelitian, nasi yang ditambahkan sari buah nanas kadar protein meningkat antara 0 dan 72 jam. Sari buah nanas memiliki kandungan kompleks, salah satunya asam sitrat. Asam sitrat digunakan dalam industri makanan dan minuman sebagai pengawet alami (Rohmana., dkk, 2015).

Nasi yang disimpan selama 0 jam memiliki rata-rata kadar protein 
0,143 ppm. Nasi yang disimpan selama 72 jam memiliki rata-rata 3,809 ppm, kadar protein meningkat sebesar 96,24\%. Menurut hasil penelitian Haq., dkk (2010) penggunaan sari buah jeruk nipis terhadap ketahanan nasi. Kandungan protein yang diukur pada nasi dengan penambahan sari buah jeruk nipis mampu mengawetkan nasi selama 96 jam dan terjadi peningkatan kadar protein pada nasi yang disimpan selama 72 jam sebesar $0,858 \%$. Kenaikan

\section{DAFTAR PUSTAKA}

Andreas, R.,2009. Masak Praktis dengan Magic Com. Noura Books. Jakarta.

Ariyadi, T dan Anggraini, H. 2010. Penetapan Kadar Karbohidrat Pada Nasi Aking Yang Dikosumsi Masyarakat Desa Singorojo Kabupaten Kenda. Prosiding Seminar Nasional Unimus 2010.

Bakhtra, D. D. A., Rusdi., dan Mardiah, A. 2016. Penetapan Kadar Protein dalam Telur Unggas Melalui Analisis Nitrogen Menggunakan Metode Kjeldahl. Jurnal Farmasi Higea. Vol 8. No 2.

Fachraniah., Elfiana., dan Elwina. 2015. Sterilisasi Cocktail Nanas Dalam Cup Plastik. Jurnal Reaksi Jurusan Teknik Kimia Politeknik Negeri Lhokseumawe. Vol 3. No 5.

Jaya, F dan Hadikusuma, D. 2009. Pengaruh Subtitusi Susu Sapi Dengan Susu Kedelai Serta Besarnya Konsentrasi Penambahan Ekstrak Nanas (Ananas comosus) Terhadap Kualitas Fisik dan Kimia Keju Cottage. Jurnal Ilmu dan Teknologi Hasil Ternak. Vol. 4, No. 1.

Haq, I. G., Permatasari, A., dan Sholihin, H. 2010. Aktivitas Penggunaan Sari Buah Jeruk Nipis Terhadap Tetahanan Nasi. Jurnal Sains dan Teknologi Kimia. Vol. 1, No. 1.

Muchtadi, D. 2009. Gizi Anti Penuaan Dini. Alfabeta. Bandung. kadar protein pada jam ke 72 terjadi karena adanya pengurangan kadar air sehingga konsentrasi protein dalam nasi menjadi lebih pekat (Haq., dkk, 2010). Penambahan sari buah nanas membuat nasi menjadi sedikit asam, sehingga mikroba tidak dapat tumbuh. Sari buah nanas juga terdapat kandungan protein sebanyak 0,4 gram dalam 100 gram nanas (Fachraniah., dkk, 2015).

Nelson, D. L dan Cox, M. M. 2006. Lehninger Principles of Biochemistry, 5ed. Worth Publisher. Inggris.

Nurcahyani, A. A dan Saptono, R. 2015. Identifikasi Kualitas Beras dengan Citra Digital. Scientific Jurnal of Informatics. Vol. 2. No 1.

Nurjanah, N dan Ihsan, N, 2013. Ancaman Dibalik Segarnya Buah dan Sayur. Pustaka Bunda. Jakarta.

Paja, D. I. 2015. Zat Aditif Makanan Manfaat dan Bahayanya. Garudhawaca. Yogyakarta.

Ray, A. 2009. Tingkatkan Fitness IQ Rahasia Tuntas Bakar Lemak dan Gaya Hidup Sehat. Libri. Jakarta.

Rohmana, Q. A., Wahyono, P., dan Hadi, S. 2015. Pengaruh Sari Buah Nanas (Ananas comosus) Dan Lama Penyimpanan Terhadap Jumlah Koloni Bakteri dan Kadar Protein Ikan Bandeng (Chanos chanos) Sebagai Sumber Belajar Dalam Perencanaan Pembelajaran Biologi Materi Kingdom Monera. Jurnal Pendidikan Biologi Indonesia. Vol. 1. No. 1.

Sherwood, L. 2012. Fisiologi Manusia. Edisi 6. EGC. Jakarta.

Sunarjono, H. H. 2008. Dua Puluh Satu Jenis Tanaman Buah. P. Swadaya. Jakarta.

Syarief, R dan Halid, H. 1993. Teknologi Penyimpanan Pangan. Pusat Antar 
Universitas-Gizi Institusi Pertanian

Bogor. Arcan. Jakarta. 